\title{
SITE SELECTION OF THE CONSTRUCTION OF THE SYSTEM FOR THE PRODUCTION OF PASTA IN AP VOJVODINA
}

\author{
Goran Paunovic ${ }^{1}$, Dragan Solesa ${ }^{2}$, Marko Ivanis ${ }^{3}$
}

\begin{abstract}
Summary
In the growing race for the market share, companies geographically position their production and office buildings according to the new business rules. In order for the company to survive in the market, it is necessary to maximize the profit, minimize the costs, maintain a good quality of the product and constantly improve it. The choice of location is one of the vital decisions in the process of building of a production system, although the selection of the location is a problem related to certain time sections in the life of a given production system, the need for research on the effect locations have is stable in time.

The aim of the research is the methodological approach to the selection criteria of broader and narrower location for the construction of the production system for pastry production in Vojvodina as an area which has a rich base in raw material. The Agricultural and food industry as branches of industry have a long time tradition as well as a great potential in strengthening economic performances of the Economy of Vojvodina. Evaluation criteria and their use in the model of dimensional analysis will allow a good selection of a good location for the construction of the business systems for the production of pastry.
\end{abstract}

Key words: business location, broader location, narrower location.

JEL: D92, L23, Q51

1 Goran Paunović M.Sc., University Business Academy in Novi Sad, Faculty of Economics and Engineering Management in Novi Sad, Cvecarska Street no. 2, 21000 Novi Sad, Serbia, Phone: +381 21400 484, E-mail: paunovicgoran.ns@gmail.com

2 Dragan Solesa Ph.D., Full Professor, University Business Academy in Novi Sad, Faculty of Economics and Engineering Management in Novi Sad, Cvecarska Street no. 2, 21000 Novi Sad, Serbia, Phone: +381 21400 484, E-mail: solesadragan@gmail.com

3 Marko Ivanis Ph.D., Associate Professor, University Business Academy in Novi Sad, Faculty of Economics and Engineering Management in Novi Sad, Cvecarska Street no. 2, 21000 Novi Sad, Serbia, Phone: +381 21400 484, E-mail: prof.drmivanis@gmail.com

EP 2017 (64) 3 (1231-1248) 


\section{Introduction}

Agriculture of Vojvodina reached its zenith during the 1980s. During the '90s, there was a decline in agricultural production according to all indicators, and the early $21 \mathrm{st}$ century brought slight recovery from the developmental collapse of the ' 90 s (Novkovic, Mutavdzic, 2009-2010). The future development of agriculture of Vojvodina can be directed towards the restoration of positive production and economic results of the ' $80 \mathrm{~s}$ but such an investment into the development of conventional agriculture will progress very slowly (Executive Council of AP Vojvodina, 2006). Vojvodina covers 35 percent of agricultural land of Serbia and the share of agricultural population in the total population of Vojvodina is under 11 percent. Grains, with 66 percent, are the most common group of crops on arable land in Vojvodina (Novkovic, Mutavdzic, 2009-2010). Although the agro-industrial sector of Vojvodina makes 40 percent of the total industrial production in Vojvodina, a significant part of agricultural products is exported in the raw state, not processed in plants. Apart from the natural comparative advantages with respect to other areas of the Republic of Serbia and neighboring countries, one of the main characteristics of Vojvodina is that it has a long tradition in the agricultural and food industry and has a professional and educated workforce. The subject of the research is based on an analysis of advantages, i.e. advantages in the choice of location $^{4}$ for the construction of a production system for pastry production in the territory of Vojvodina. Natural factors such as: the characteristics of the relief, natural wealth, availability of raw materials, energy and water resources, soil fertility, and the overall ecological and climatic conditions are the advantages that characterize this area. Man-made resources, such as the development of large networks and community infrastructure, the quality of the overall developmental foundation such as: structure of urban economy, industrial tradition, educational structure of workforce, development of educational-information system, the level of general culture, the level of organization of urban space, differ among some municipalities in the territory of Vojvodina, and such factors will be taken into consideration in the case study. Natural location factors determine the total locational capacity (potential) and man-made resources determine the optimal scope of utilization of the given natural resource in each stage of the development process. Economic and overall social development have led to the situation where man-made resources gradually outweigh the natural comparative resources. When choosing a location for pastry production, attention was primarily paid to the minimizing of production costs. The complexity of the analysis of the simultaneous effect of several factors implies that when choosing a location other factors of importance are also analysed. The main inputs in pastry production process are wheat and water. Pastry is a product obtained by mixing and shaping wheat semolina or flour with water (plain

4 For a good choice of location, three main components of the scientific method are applied. By applying the general approach through certain scientific findings in this field, the methodological approach to selecting the criteria of broader and narrower location, methods and research techniques to analyse the criteria, we will provide an evaluation of influencing factors of importance for the choice of location. 
pastry) or mixing and shaping of basic raw materials with the use of additional raw material (modified pastry) (Official Gazzette of RS 43/2013). In terms of quality, the water used in the production of pastry needs to meet the requirements prescribed for drinking water. For these reasons, the locations that do not meet the requirements for drinking water quality have to be eliminated regardless of the attractiveness of other factors. Pastry is not seasonal goods, so the sales are uniform throughout the year. In Serbia, pastry is used by as much as 88 percent of consumers and the percentage of users is generally stable.

\section{Location Theory}

The strategic importance of logistics is increasing and companies need efficient logistical support to achieve competitive advantage. The decision on the selection of the optimal location has a significant impact on customer service and logistics costs. The choice of location is a complex process in which to consider multiple, tangible and intangible criteria. However, many of the current methods of supporting the process of cost-orientation (Korpela, Tuominen, 1996).

Selection of industrial sites is a strategic decision that involves several criteria: technical, economic, social, environmental and political. Deciding that the site requires appropriate instruments to enable data collection, storage, analysis, fusion and knowledge management to solve this complex problem (Rikalovic et al., 2015).

Capello (2011), includes the location as an economic resource and an independent factor of production, generator of static and dynamic advantages for companies.

Perceptions in the location theory have changed under the influence of many factors. Technological development, the increasing mobility of production factors and socioeconomic changes have influenced the rapid change of the priority criteria scale. The emergence of the location theory is linked to Alfred Weber, who, in his research of the optimal location in terms of industrial facilities, in addition to the difference in transportation costs and labor costs, introduced agglomerative-deglomerative factors in the analysis (Weber, 1909). Agglomerative factors encourage the concentration of the industry, due to the possibility of technical improvements in terms of specialization of machines and plants and the establishment of cooperation among participants within the same branch. Deglomerative factors lead to the decentralization of industrial facilities, due to the high cost of leasing the larger areas of land. For this reason, Weber introduced the scheme of concentric circles that indicate points with equal transportation costs. In order for these circles of locational indifference to mark boundaries between the zones of equal locational advantages, which he calls isodapanes, where the greatest locational advantages (i.e. the lowest costs of location) are in the center of such a scheme, Weber also included other locational factors which may substitute transportation costs with possible savings on other locational factors. The change in the point of view caused by the development of industrialization and its interdependence with the development of tertiary services has caused the market to be perceived as a field bordered by concentric 
circles of locational indifference around the points which are suitable for the location of industrial facilities. The intertwining of these markets for different products leads to the analysis of economic regions or surrounding areas of the "central places", which is subsequently developed in the theory of regional development (Milicevic, 1990).

Results indicate that the choice of location means a simple decision-making process and to provide a starting point towards a systematic dissection of the process (ChungHui et al., 2008).

\section{Location of Production Systems}

The complexity of the business system structure and the relationship with the surrounding area, changes in market demands, conditions for the provision of inputs, features of the production program, economic conditions, labor conditions, waste matter and other influences determine the location of new production systems, whereas the changes to the production programs, characteristics of the work process, frequency of technological changes and the effect of disorders necessitate an adjustment of the location of the existing production systems (Zelenovic, 2012). The process of location selection is determined by identifying the influential factors of objective and subjective character, which are different in intensity and direction of the action, their evaluation and selection of an optimal location. For the choice of the broader and narrower location we will apply dimensional analysis model based on the relationship between the two measurable locations.

$$
R=\frac{V_{L 1}}{V_{L 2}}=\left(\frac{O_{L 1}}{O_{L 2}}\right)^{W 1} \times\left(\frac{O_{L 1}}{O_{L 2}}\right)_{2}^{W 2} \times\left(\frac{O_{L 1}}{O_{L 2}}\right)_{3}^{W 3} \times \ldots \times\left(\frac{O_{L 1}}{O_{L 2}}\right)_{m}^{L W /}
$$

Where if $\mathrm{R}<1$, the location $\mathrm{L} 1$ represents a better solution, i.e. if $\mathrm{R}>1$, the location $\mathrm{L} 2$ represents a better solution. The quality of location's favorability grade depends on the quality of data which determine the values (Oi) and the degree of goodness of the value of the relative importance - wi factor's effect (Zelenovic, 2012).

\section{Case study - overview of methodological research procedure}

The procedure of location selection takes place in five steps: problem identification through a choice of a favorable location in terms of stability and development of production, identification of influential factors in the choice of a broader and narrower location, evaluation of influential factors, such as subjective and objective effects, as well as the critical effects which condition a certain solution, evaluation of the relative importance of influential factors, where the least important factor has the lowest value and the choice of location. 


\section{Places in the area of broader location}

The choice of a broader location for the construction of a production system for pastry production is in the territory of Vojvodina, which is a region rich in raw material. This phase of research involves "library work" through the use of tertiary sources, "field work" in the sense of using local data ${ }^{5}$ and the production of a preliminary draft of research through the analysis of the factors, their evaluation, and assessment of the relative importance which will enable the analysis of the location selection by using the dimensional model. The Municipality of Titel and the Municipality of Vrbas will be considered for the broader location.

Figure 1. Representation of the Municipality of Vrbas

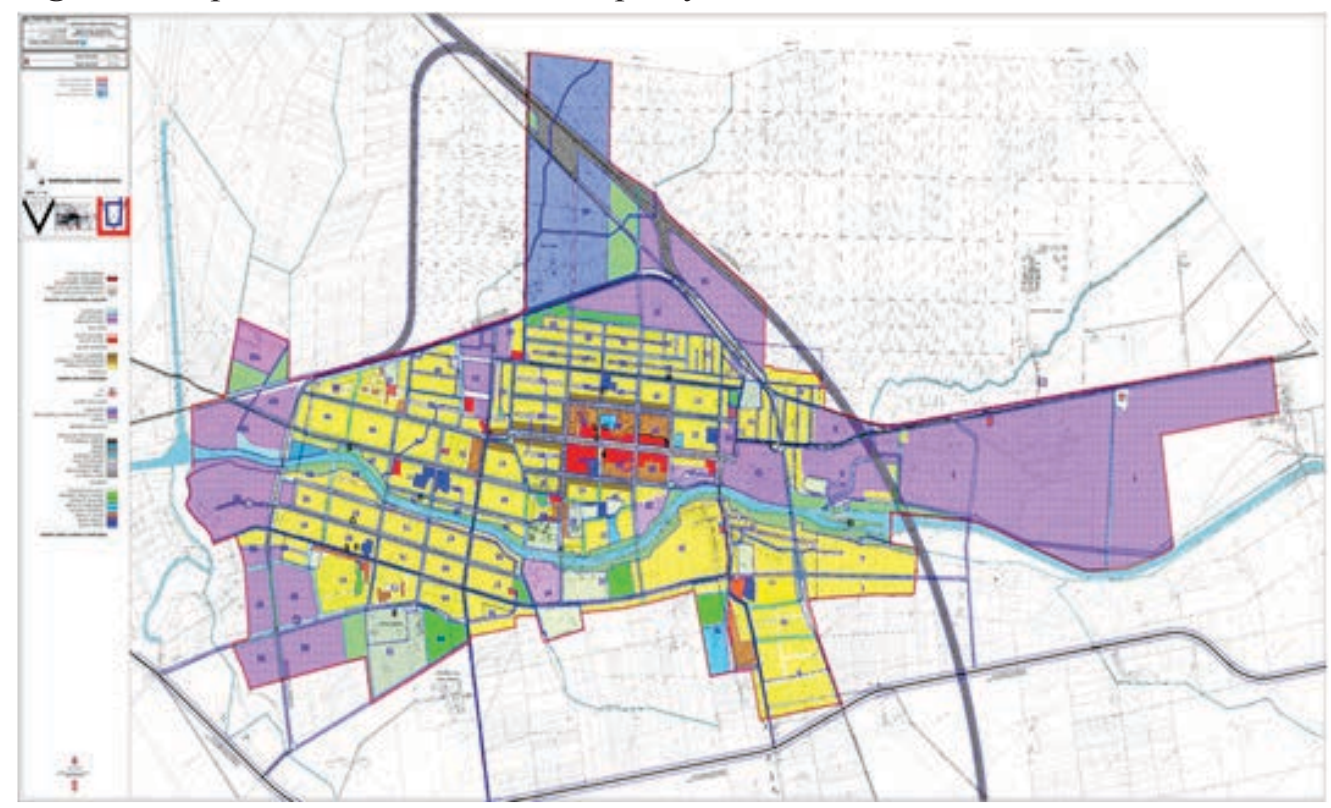

Source: Directorate for Construction of Vrbas

A favorable geographic and transport position enables the Municipality of Vrbas to become a significant center of the central Bačka. Vrbas is at the crossroads of major routes for different modes of transport, thus connecting it with other parts of Vojvodina. An abundance of natural resources and a favorable climate form the basis for the development of agriculture and food industry, which has a long tradition in the Municipality of Vrbas.

The Municipality of Vrbas has an educated and motivated workforce, with a strong entrepreneurial potential. The development of the infrastructure, the financial sector and public institutions classify Vrbas as one of the most important centers in Serbia. Pollution of the Great Bačka Canal is one of the major weaknesses of the municipality, which in addition to the impact on the environment, prevents the development of river

5 By using local data, Official Gazzettes of the municipalities, the special plan etc.

EP 2017 (64) 3 (1231-1248) 
transport and tourism. The industrial zones are insufficiently equipped, which slows down economic development and job creation. Unfavorable demographic indicators are reflected in the outflow of human resources as well as in the negative natural population growth.

Figure 2. Representation of the Municipality of Titel

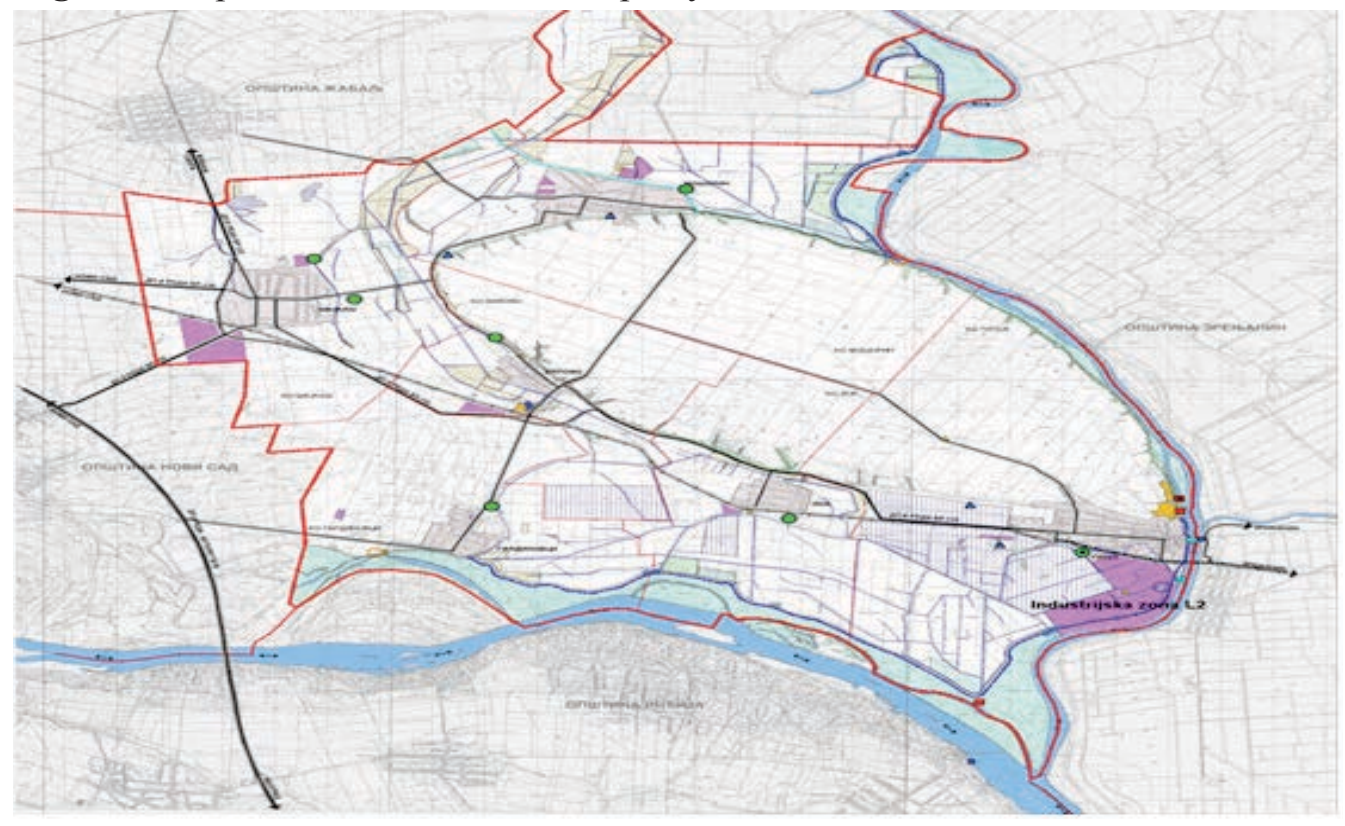

Source: Planning Institute of Vojvodina

The Municipality of Titel is in the center of Vojvodina at the confluence of the Tisza and the Danube rivers. The Municipality of Titel is an area of 263.5 square kilometers which includes 6 towns: Titel, Ilok, Vilovo, Gardinovci, Šajkaš and Mošorin. Titel is a town on three rivers. It is situated on the right bank of the river Tisza. Here the river Begej flows into the Tisza and $9 \mathrm{~km}$ to the south Tisa flows into the Danube. Carska Bara, a unique natural reserve of flora and fauna, is situated in the vicinity of Titel. Titel is located $50 \mathrm{~km}$ from Belgrade, $40 \mathrm{~km}$ from Novi Sad and $30 \mathrm{~km}$ from Zrenjanin. The advantages of the Municipality of Titel are as follows: developed infrastructure, proximity to navigable rivers, the largest $\mathrm{C}$ class airport in the Balkans, transport links to major cities, ecologically clean area and qualified workforce. The Municipality of Titel is one of the economically less developed municipalities in Vojvodina. Agricultural production accounts for 65 percent of the gross income of the municipality, focused mostly on crop production, and with a smaller share of livestock and vegetable production. The Municipality of Titel has all the prerequisites for profitable agricultural production with the possibility of treatment and processing of agricultural products.

With certain investments, agriculture could become one of the major driving factors in the development of the municipality. Regulation of the riverside of the river Tisza 
in Titel is being planned, where a cargo port Luka Titel will be built according to the project solution. The industrial zones, covering the area of about 300 ha, can be found on several locations and are connected with roads, railway and navigable rivers with large centers such as Belgrade, Novi Sad and Zrenjanin. The free industrial zone at the site of block 65 covers the area of 50 ha and is equipped with complete infrastructure.

\section{Choosing a place in the broader location}

Broader location as an area that meets the basic requirements for the construction and development of a production system is conditioned by the characteristics of the production program. The municipalities of Vrbas and Titel will be considered as the broader location for the construction of a business system for the production of pastry in Vojvodina because these municipalities have a developed agricultural production. Among the range of significant factors for the choice of a broader location the following factors are distinguished:

- Source location is important since wheat is the main raw material for pastry production. The price of wheat depends on the yield and the demand in the world market and it is currently between 17-18 dinars per kilogram. Both locations are situated in a favorable area, so this factor will not be discussed.

- Social stability and legal certainty is a significant factor in the selection of a location on the international level. Presuming that the investor opted for the area of the broader location, this factor will not be discussed.

- Destination location is determined by the structure of a consumer network, terms and time of delivery and high transportation costs. The price of pastry per kilogram ranges from 100 to 400 dinars. During storage and transport there is no need for specific storage conditions since it does not belong to perishable goods. Based on the parameters such as small transport costs and a high price of the product, the destination location is not of great significance, but from the standpoint of access to major roads - terms and time of delivery, this factor is of importance. One of the characteristics of the Municipality of Titel is that the II category public road no.110 connects all the towns and villages with the center of the Municipality of Titel and the surrounding area. This area is located near the highway. However, a segment of the II category public road no. 122 has not been built, on the section from Šajkaš to the highway even though it represents a very important road that reduces the trajectory of movement of all vehicles which would use the II category public road no.122 (Planning Institute of Vojvodina, 2005).

- With regard to the development of the road network, Vrbas is at the top level in the area of Vojvodina. There is the E-70 highway, the I category public road (arterial) as well as the union of the II category public roads (regional roads) which enable good communication with the surrounding area (Planning Institute of Vojvodina, 2005). 
- Availability of traffic (destination location) for the location L1 is not a factor of importance because this area has a constructed road infrastructure. It is an important factor for the location L2 because of the underdeveloped road network.

- $\mathrm{W}^{6}=3$. According to the detailed regulation plan, the location L1 has a very good road network, so the value of the subjective factor is 1 . For the location L2, the factor is of higher importance because a segment of the II category public road, which would connect it to the highway, has not been built, so the value of the subjective factor is 4 .

- Energy, water and fuel are of a great importance for the choice of the location of the production system for pastry production since drinking water is used in the production process. For the location L1 this factor is of minor importance because centralized urban water supply systems are developed and water is of good quality. For the location of L2 this factor is important due to the reasons connected to the exploitation of water from artesian aquifers. The water from these aquifers contains a higher quantity of humic substances (mostly yellow) and often with illegal quantity of some microelements (arsenic) (Strategy of water supply and water protection in the AP of Vojvodina, 2009).

- $\mathrm{W}=5$. For the location $\mathrm{L} 1$, the factor is of minor importance because of the good water quality so the value of the subjective factor is 2 . For the location L2, the factor is of higher importance because of the poor quality of water, so the value of the subjective factor is 4 .

- Participants in the working processes have an impact on the choice of location. Both locations are characterized by high unemployment. Decrease in the number of employees has caused the fall of GDP, which is $1.7 \%$ per annum in the Municipality of Vrbas. For these reasons, the Municipality of Vrbas has adopted the Action Plan for Employment (Official Gazette of the Municipality of Vrbas No.1 / 2014). The same situation is the case with the Municipality of Titel, which is one of the economically underdeveloped municipalities in Vojvodina. Due to the high rate of unemployment in both municipalities, the factor will not be discussed.

Table 1. Tabular representation of the municipalities of Vrbas and Titel

\begin{tabular}{|l|c|c|l|l|l|c|}
\hline & $\begin{array}{l}\text { Number of } \\
\text { inhabitants }\end{array}$ & $\begin{array}{l}\text { Monthly } \\
\text { net } \\
\text { income }\end{array}$ & $\begin{array}{l}\text { Number } \\
\text { of the } \\
\text { employed }\end{array}$ & $\begin{array}{l}\text { Number of } \\
\text { the } \\
\text { unemployed }\end{array}$ & $\begin{array}{l}\text { Unemployment } \\
\text { rate }\end{array}$ & $\begin{array}{l}\text { Monthly } \\
\text { gross } \\
\text { income }\end{array}$ \\
\hline $\begin{array}{l}\text { Municipality of } \\
\text { Vrbas }\end{array}$ & 41950 & 324 & 9258 & 7606 & $44 \%$ & 451 \\
\hline
\end{tabular}

6 W- relative importance for "determining the relative importance of the factors is in the range from 1 to 10 , where the critical factor receives the importance of 10, and the least important factor, the value of 1 ". 


\begin{tabular}{|l|c|c|c|c|c|c|}
\hline $\begin{array}{l}\text { Municipality of } \\
\text { Titel }\end{array}$ & 15554 & 258 & 1751 & 1454 & $40 \%$ & 355 \\
\hline
\end{tabular}

Source: Serbian Development Agency (RAS) Database of Municipalities, (2016), URL:// http://serbia-locations.rs/

- Reliability of the participants' behavior in the process of work is characterized by precision at work, responsibility and other requirements.

The production of pastry is characterized by a large scale production; therefore, the workers can have a lower level of qualifications (one worker can perform multiple types of operations) and this factor is insignificant.

- Economic conditions, services and cost of living are not much different between the aforementioned municipalities this factor will not be discussed.

- Waste matter and environmental protection present factors of great significance.

An increase in the capacity of resources for environmental protection by the Municipality of Vrbas and the Ministry for Environmental Protection of the Republic of Serbia and the engagement of leading foreign and domestic institutes in the field of water protection have helped to form a comprehensive solution for the revitalization of the Great Bačka Canal, which has become the most polluted waterway in Serbia, as well as in the whole Europe. The solution, which is in the development phase, includes systems for collecting (sewage network in Vrbas and Kula), transportation (inter-city collector Vrbas-Kula) and filtering of wastewater and revitalization of the Great Bačka Canal, which passes through the town of Vrbas in the length of $6 \mathrm{~km}$. One advantage of the municipality of Titel is the ecologically clean environment, so this factor will not be discussed. For the location L1, this factor is of absolute significance, whereas for the location L2 this factor is standard.

$\mathrm{W}=5$. Since the revitalization of the Great Bačka Canal is of absolute significance for the location L1, the subjective factor value equals 5, whereas for the Municipality of Titel, which is ecologically clean, the value of the subjective factor equals 2 .

- Climate conditions are of utmost importance for the location of the production system; since climate conditions in these two regions are almost the same, this factor will not be discussed.

- Possibilities for the development of the production system do not differ significantly between the aforementioned municipalities and therefore will not be discussed.

- Involvement of the local community (local government and self-government) is of great importance for making an economic environment for attracting investments, development of infrastructure and efficient administration. The 
location L1 covers the area of 14.2 ha which is subdivided into two plots of land - 88.1 and 88.2. It is situated between the road to Srbobran in the southwest, the border of building land in the northwest, the planned main road in the southeast and the border of building land of the municipality of Vrbas in the northeast (Official Gazette of the Municipality of Vrbas number 8/12). The other location L2 is situated in Titel, in the south-I industrial zone. It is fully equipped with communal infrastructure for the production activities and it covers the area of 281.39 ha; it is well-connected with roads, railroads and water channels with a residential area in the vicinity (Official Gazette of the Municipality of Titel number 4/2012). For the reasons given, this factor is significant for the first location L1 because the plot does not have complete infrastructure. For the location L2 it is standard since it has communal infrastructure.

$\mathrm{W}=4$ Since the involvement of the local community is of great significance for the location L1for the purpose of fast communal installation of the industrial zone, the subjective factor value is 4 , while for the location L2, which is subdivided into parcels, this value equals 2 and is not essential.

Subjective factors are graded on the scale of significance in the following manner: the more significant the factor, the bigger the value and vice versa - the less significant the factor, the smaller the value. In the next phase, the relative significance of influential factors will be graded in such a way that the crucial factor will have a bigger value and the less important factor will have a smaller value. The recorded values will be added to the table (1.4). In the last phase, the location will be chosen according to the ratio of location values by implementing the Bridgman (1963) model of dimensional analysis.

Table 2. Choice of broader location

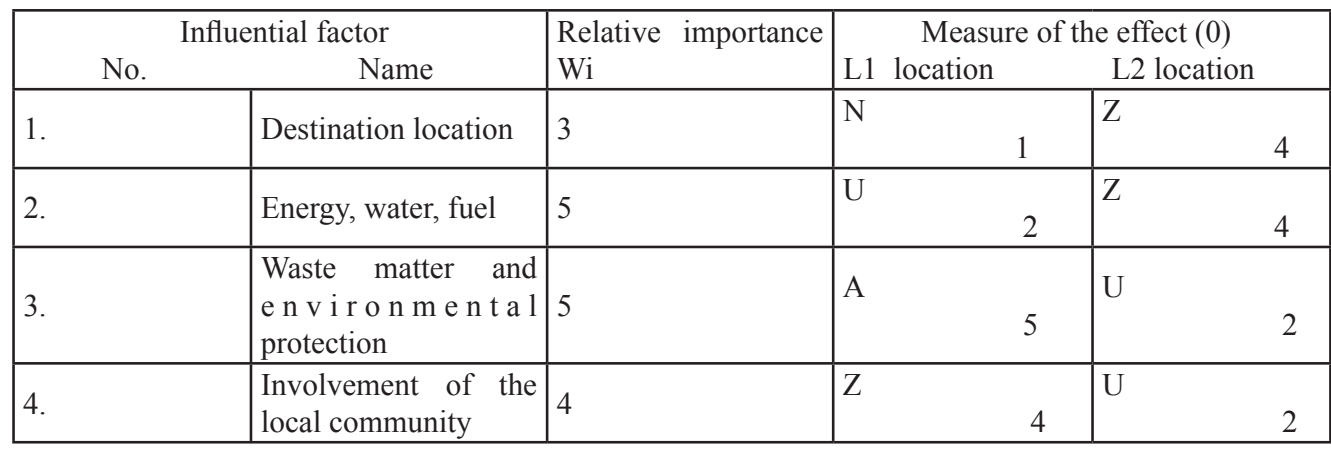

Source: Work of authors.

The ratio of location values:

$$
R=\frac{V_{l 1}}{V_{l 2}}=\left(\frac{1}{4}\right)^{3} \cdot\left(\frac{2}{4}\right)^{5} \cdot\left(\frac{5}{2}\right)^{5} \cdot\left(\frac{4}{2}\right)^{4}=0,7629
$$


From which we conclude that location L1 presents a more favorable solution according to given conditions.

\section{The results of the study of factors which influence the choice of broader location}

The locations L1 and L2 have their advantages. The location L1has a better road access according to the urban development scheme, the possibilities for expansion are favorable and the quality of water is better than on the location L2 which presents an important parameter since the production of pastry requires good water quality. The location L2 has cheaper building land as well as complete communal infrastructure. Having evaluated the effects for the choice of broader location, the location L1 is found to be more favorable for the construction of the pastry production system, which gives us a good foundation to further analyze the factors for the selection of a more precise location - the exact place for the construction of the production system on the territory of the Municipality of Vrbas.

\section{The selection of a more precise location for the construction of the pastry production system in the Municipality of Vrbas}

The precise location is a place on the territory of the broader location which meets the requirements for the process of work and alleviates limitations posed by the environment (Zelenovic, 2012).

Figure 3. Location L1

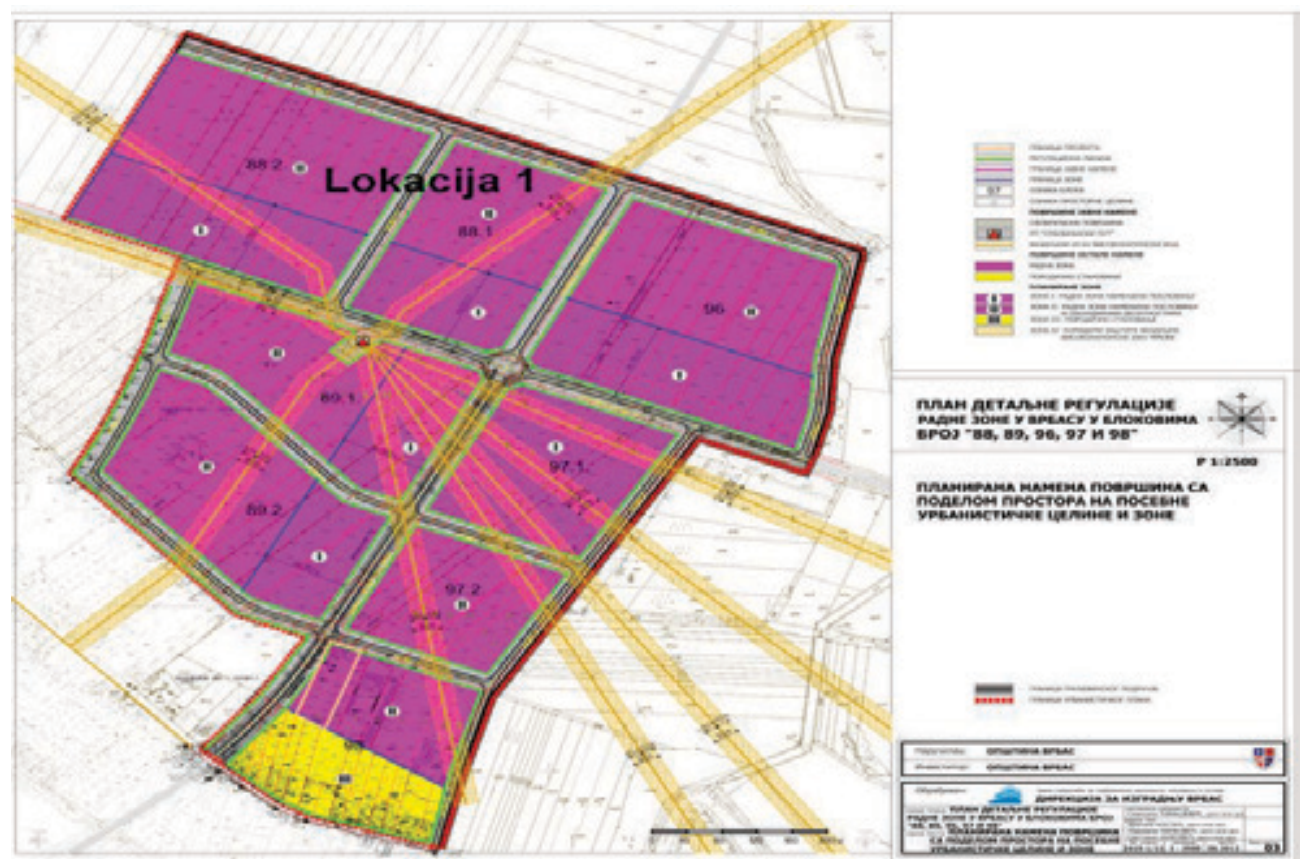

Source: Directorate for Construction of Vrbas 
The first location (L1) covers the area of 14.2 ha and it includes the block 88 which is divided into two plots, 88.1 and 88.2. It is situated between the Srbobran road in the southwest, the border of building land in the northwest, planned main road in the southeast and the border of construction land of the Vrbas town in the northeast. The plan includes routes, directions of networks for water supply, and the reserved building land for public purpose, corridors of networks for water supply which will include the future network according to the plan. Until the planned waterworks have been built, in specific cases the need for water supply in the area planned for other purposes can be fulfilled by excavating water wells on the users' parcels. In the area included in the plan, there is no sewage network for draining waste and atmospheric water. A separating type of sewage network should be considered for these blocks to collect fecal waste water on one channel and atmospheric water in the other channel. The block 88 would be supplied with electrical energy from a new RP $20 \mathrm{kV}$ source 'Srbobran Road'. The plan has been developed for the $20 \mathrm{kV}$ cable line to be set on public land which will provide power supply for blocks 88 and 96 . The construction of heating system was not planned. The consumers' requirements for heating energy will be satisfied by a distributive natural gas system or using other, individual sources of energy depending on the required capacity. This area will be completely integrated into Vrbas telecommunication system (Directorate for Construction Vrbas, 2012).

Figure 4. Location

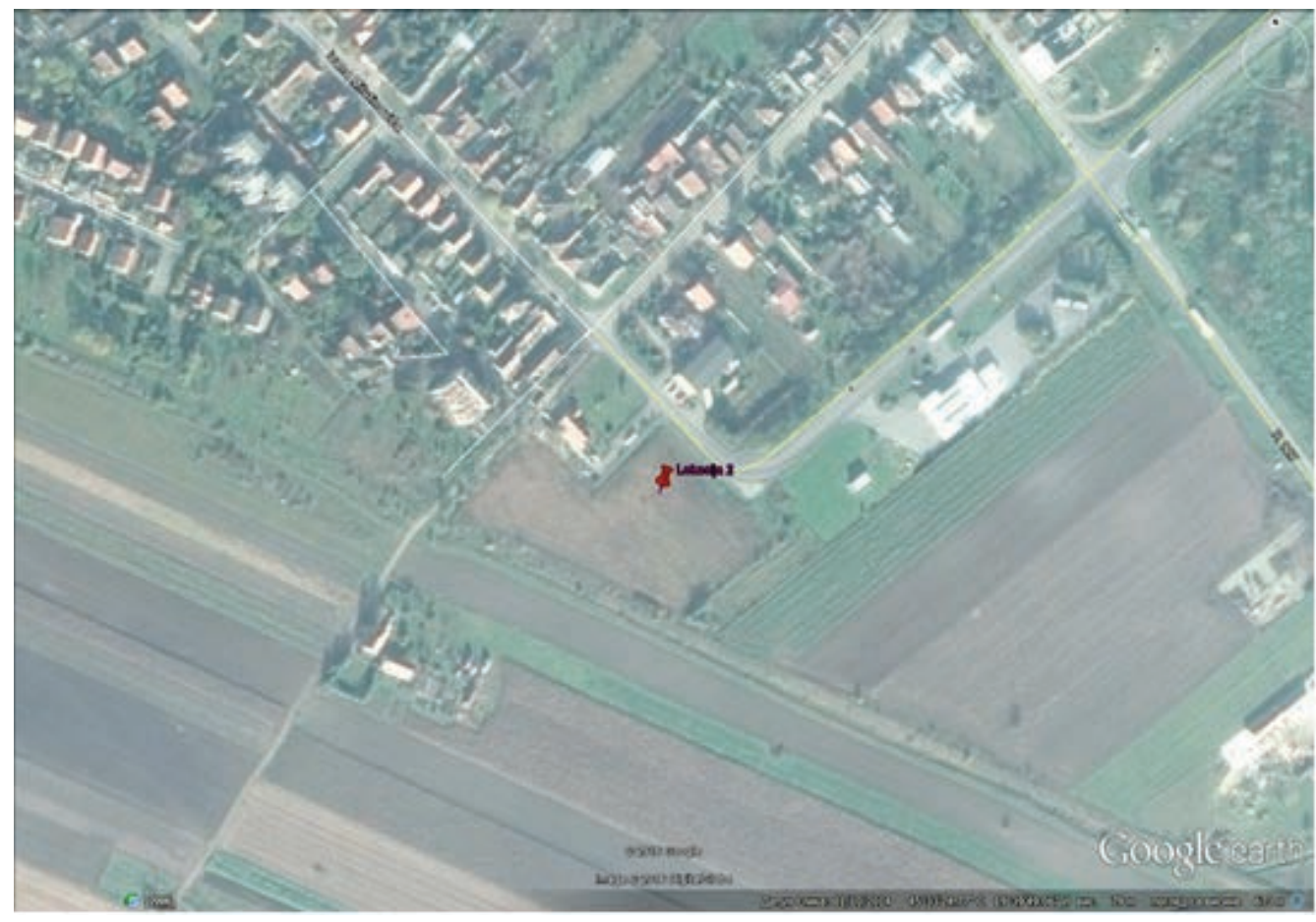

Source: Google Earth 
The second location (L2) covers the area of 0.75 ha and is situated in the settlement at the end of Ivana Milutinovića Street in the 4th Industrial zone, along the road to Novi Sad. The price of land is 1200 dinars per square meter. The plot has water, electricity and telephone installations. The disadvantage of this parcel is the fact that it is located in the residential area?.

- The size of the area is of great importance for the selection of location for the production system. The location L2 is situated on the area of 7500 square meters which is insufficient for a large scale production; if we take Danubius for example, its facilities cover the area of 10520 square meters, not counting the silos with 6800t capacity. The Indonesian Company "IndoAdriatic Industry" spans over the 5 ha parcel and is in the process of building of the production system. The location L1 is in the area of two sub-plots 88.1 and 88.2 with the total of 14.2 ha which, apart from the establishment of the working units, provides the possibilities for expansion, as well as for the construction of other facilities such as for sports and recreation, green areas and the like ${ }^{8}$. This factor is insignificant for the location L1 for the given reasons, while it is significant for location L2 because of the aforementioned limitations.

$\mathrm{W}=4$ The location L1spans over a large area so this factor is of smaller importance which makes the subjective factor value 1 . The location $\mathrm{L} 2$ does not include the area which would provide a possibility for expansion of production systems and potential additional facilities so the subjective factor value here is 5 .

- Residential zones are determined by the distance between the residential area and the location of the production system. Since both locations are in the direct vicinity of the residential zone, this factor will not be discussed.

- Available communication is of great importance for the selection of exact location from the perspective of distance of the given location from available communication as well as the possibility for the construction of an industrial railroad. The location L1 is situated between the Srbobran road in the southwest, the border of building land in the northwest, the planned main road in the southeast and the border of building land of the Vrbas town in the northeast. Because of its favorable position and good connections this factor is standard. The location L2 is situated near the road to Novi Sad in the residential area, so this factor is necessary since the residential area is not a suitable place for a large scale industrial production.

$\mathrm{W}=3$ The location $\mathrm{L} 1$ is well connected with main roads and it is not situated in a residential area so this factor is less important and the subjective factor

7 http://www.gohome.rs/nekretnine+vrbas

8 Construction of the production system can be on one of the two sub-plots or a part of the subplot $(88.1,88.2)$, depending on the size of the production facility.

EP 2017 (64) 3 (1231-1248) 
value is 2 . The location L2 is situated in the vicinity of the road to Novi Sad in a residential area so this factor is more important and the subjective factor value is 3 .

- The climate is very important for the selection of the location for the production system. The direction and intensity of air currents must be studied in detail, especially for the production systems which cause pollution to the environment. Therefore, this factor could be important. For the location L1, this factor is standard since it is situated outside the residential area. For the location L2, this factor is necessary because this plot is in a residential area.

$\mathrm{W}=3$ The location $\mathrm{L} 1$ is situated outside the residential area so the subjective factor value is 2 . For the location L2, the subjective factor value is 3 because the parcel is located in the residential area.

- Price of land is important for the choice of both locations. This factor will be expressed in financial units by comparing the available size of the plot L 2 with the given price per square meter. "The recommendation is that the proportion of the built production and supporting area is 30 to 40 percent of the total area, so there is the possibility of expanding the system" (Vranjes et al., 2002).

$\mathrm{L}^{9}$ : $7500 \mathrm{~m} 2 \times 1,010.20 \mathrm{din}=7,576,500.00 \mathrm{din}$

$\mathrm{L} 2^{10}: 7500 \mathrm{~m} 2 \times 1,200.00 \mathrm{din}=9,000,000.00 \mathrm{din}$

$\mathrm{W}=1$ This factor is equal because the difference in price is approximate to equipping the L1 plot.

- Noise and radiation present specific factors for the selection of the location for the production system. For the location L1, this factor is standard because it is situated in the industrial zone while for the location L2 it is significant because it is situated in a residential area.

$\mathrm{W}=3$ The location L1 is situated in the industrial zone where other production systems which produce noise can also be found so this factor is not significant and the subjective factor value is 2 .

The location L2 is situated in a residential area where this factor is of bigger significance and the subjective factor value here is 4 .

- Underground water and availability of services present factors of significance; these factors will not be discussed since they are equal at both locations.

For the purpose of selection of the location for the construction of the production system, all significant factors which affect the quality of choice have been taken

9 Price of land for location L1 published in the Official Gazette of the Municipality of Vrbas No. 9/14

10 Price of land for location L2, http://www.gohome.rs/nekretnine+vrbas 
into account. The influential factors such as residential areas, underground water and availability of services have not been evaluated since they are equal on both locations. Significant factors for the quality of choice such as area size, availability of communication, the climate, price of land, noise and radiation have been considered and evaluated. The values of these significant factors are given in the (Fig. 7) table. Financial value of the price of facility is equal assuming the fact that the investor is aware of the size and capacity of production, so the cost of construction on both locations would be the same.

Table 3. Choice of a narrower location

\begin{tabular}{|c|c|c|c|c|}
\hline \multirow{2}{*}{\multicolumn{2}{|c|}{$\begin{array}{l}\text { Significant factor } \\
\text { No. } \quad \text { Name }\end{array}$}} & \multirow{2}{*}{$\begin{array}{l}\mathrm{R} \text { e } 1 \text { a } \mathrm{t} \text { i v e } \\
\text { significance } \mathrm{Wi}\end{array}$} & \multicolumn{2}{|c|}{ Measure of the effect $(\mathrm{O})$} \\
\hline & & & L1 location & L2 location \\
\hline 1. & \begin{tabular}{|l|} 
Price of land \\
(din)
\end{tabular} & 1 & $7,576,500$ & $9,000,000$ \\
\hline 2. & $\begin{array}{l}\text { Price of facility } \\
\text { (din) }\end{array}$ & 1 & $126,000,000$ & $126,000,000$ \\
\hline 3. & $\begin{array}{l}\text { The climate } \\
\text { (points) }\end{array}$ & 3 & $\mathrm{U}$ & $\mathrm{P}$ \\
\hline 4. & $\begin{array}{l}\text { A } \mathrm{v} \text { a i } \mathrm{l} \text { a b } \mathrm{l} \\
\mathrm{com} \text { m unication } \\
\text { (points) }\end{array}$ & 3 & U & $\mathrm{P}$ \\
\hline 5. & $\begin{array}{l}\text { Noise and radiation } \\
\text { (points) }\end{array}$ & 3 & $\mathrm{U}$ & $\mathrm{Z}$ \\
\hline 6. & $\begin{array}{l}\text { Area size } \\
\text { (points) }\end{array}$ & 4 & $\mathrm{~N}$ & A \\
\hline
\end{tabular}

Source: Work of authors

Location-value ratio

$$
R=\frac{V_{l 1}}{V_{l 2}}=\left(\frac{7.576 .500}{9.000 .000}\right)^{1} \cdot\left(\frac{126.000 .000}{126.000 .000}\right)^{1} \cdot\left(\frac{2}{3}\right)^{3} \cdot\left(\frac{2}{3}\right)^{3} \cdot\left(\frac{2}{4}\right)^{3} \cdot\left(\frac{1}{5}\right)^{4}=0,00001478
$$

Which concludes that the location L1 is more favorable for the given conditions.

\section{The results of the study of factors which affect the selection of the exact location}

Despite the unfinished communal infrastructure, the location L1 presents a more favorable solution than the L2 location because it is situated in the industrial zone which provides the possibility for expansion of production capacity, it has a better road access according to the town planning scheme, the noise has no significant effect since the location is outside the residential area. Along with fast and efficient municipal administration, this location presents a long-term and quality solution. 


\section{Conclusion}

The territory of the AP of Vojvodina, apart from its favorable geographic location, abounds in diverse regional structures and resources which provide good conditions for economic development and high standard of living. Favorable natural conditions and constructed economic capacities are not evenly distributed in all areas. As a result, conditions for future economic development are not equal. In the process of planning, arrangement and use of space, the activities should be especially directed towards valorization of natural resources in less developed areas and making a better economic and social infrastructure in order to compensate for regional differences in economic development. One of the main characteristics of the area is the fact that the economy is not synchronized with European and international norms, with industrial products which are not competitive enough, as well as a high deficiency in the trade balance. Unequal development has caused the demographic drain of rural areas and high polarization. For the industrial and economic development in general, it is necessary to raise the competitiveness, which means that the idea of cheap and underqualified labor and natural resources as bases for development must be reconsidered and abandoned. The development must be based on technological revitalization, competitive production with fully integrated sophisticated technological solutions. The studies of factors which affect the choice of a narrower location are related to certain chronological analyses of the production system. The elements relevant to the process of selecting the location for the production system have been determined based on a systematically oriented approach. The complexity of structures of business system and the relations with the environment, changes in market demand, conditions of procurement of input values, characteristics of the production program, economic conditions, work conditions, waste matter and other factors present the parameters which have been taken into account in the research in order to select the location for the production system. Having analyzed the areas of the municipalities of Vrbas and Titel as well as the specific features of these two locations, the conclusion has been reached that the Municipality of Vrbas presents a more favorable solution because of its good traffic infrastructure as well as water quality, which is a significant factor since drinking water is used in the production process. Possibility for expansion, as well as noise and radiation as factors have influenced the choice of the narrower location to be block 88 which is subdivided into two plots , 88.1 and 88.2. Objective and subjective factors, their evaluation on the basis of data quality and their implementation in the dimensional analysis model have helped to make a good proper selection of the location for the construction of the production system on the territory of the AP of Vojvodina.

\section{Literature}

1. Bridgman, P.W. (1963): Dimensional Analysis, Connecticut, Yale University Press, New Haven and London.

2. Capello, R. (2011): Location, regional growth and local development theories. Aestimum, Vol. 58, pp. 1-25. 
3. Chung-Hui Y., Priyanka B., Ernst H., Lily Y. J., Yuh-Nung J. (2008): Drosophila egglaying site selection as a system to study simple decision-making processes, Science, Vol. 319 Issue 5870, pp. 1679-1683.

4. Direkcija za izgradnju Vrbasa (2012): Plan detaljne regulacije radne zone u Vrbasu u blokovima 88, 89, 96, 97, 98, Vrbas.

(available at: http://www.vrbas.net/e-uprava-vrbas/službenilist)

5. Izvršno veće AP Vojvodine (2006): Program privrednog razvoja AP Vojvodinenovelirana ex post analiza privrede AP Vojvodine, Novi Sad, (available at: http:// vojvodina-rra.rs/studije-analize.html)

6. JP Zavod za urbanizam Vojvodine (2005): Strategija razvoja i kategorizacije putne mreže u Vojvodini, Novi Sad, (available at: http:/www.zavurbvo.co.rs/doc./studije/)

7. JP Zavod za urbanizam Vojvodine (2008): Prostorni plan opštine Titel, Službeni list 17/08, Novi Sad,

(available at: http://www.zavurbvo.co.rs/prostorni.php)

8. Korpela, J., Tuominen, M. (1996): A decision aid in warehouse site selection, International Journal of Production Economics, Vol. 45, Issues 1-3, pp. 169-180.

9. Milićević, G. (1990): Urbana ekonomika, Ekonomski fakultet, Beograd.

10. Nekretnine Vrbas, (available at:

http://www.gohome.rs/nekretnine+vrbas)

11. Novković, N., Mutavdžić, B. (2009-2010): Konkurentnost poljoprivrede Vojvodine, CESS, Novi Sad.

12. Pokrajinskisekretarijatzanaukui tehnološkirazvoj(2009): Strategija vodosnabdevanja i zaštite voda u AP Vojvodini, (available at:

http://www.ekovrb.vojvodina.gov.rs/)

13. Pravilnik o kvalitetu žita, mlinskih i pekarskih proizvoda, testenina i brzo smrznutih testa (2013): Official Gazette of the RS 43/2013, Beograd, (available at: http://www. tehnologijahrane.com/pravilnik/pravilnik-kvalitetu-ita-01)

14. Ras baza opština (2016), (available at: http://serbia-location.rs/)

15. Rikalovic, A., Cosic, I., Labati, R. D., Piuri, V. (2015): A Comprehensive Method for Industrial Site Selection: The Macro-Location Analysis. IEEE Systems Journal.

16. Official Gazette of municipality of Titel, 4/2012. (available at: http://www.opstinatitel.rs)

17. Official Gazette of municipality of Vrbas, 8/12, 9/12, 9/14, (available at:

http:/www.vrbas.net/e-uprava-vrbas/službenilist)

18. Univerzitet u Novom Sadu, Prirodno matematički fakultet, departman za hemiju, (2009): Strategija vodosnabdevanja i zaštite voda u AP Vojvodini, (available at: www. ekovrb.vojvodina.gov.rs/)

19. Vranješ, B., Jerbić, B., Kunica, Z. (2002): Projektiranje proizvodnih sustava, Školska knjiga, Zagreb. 
20. Zelenović, D. (2012): Projektovanje proizvodnih sistema, Fakultet tehničkih nauka, Novi Sad.

21. Weber, A. (1990): Ueber der Standort der Industrien, Tübingen, J.C.B. Mohr (Paul Siebeck).

\title{
IZBOR LOKACIJE ZA IZGRADNJU POSLOVNOG SISTEMA ZA PROIZVODNJU TESTENINA U AP VOJVODINI
}

\author{
Goran Paunovic ${ }^{11}$, Dragan Solesa ${ }^{12}$, Marko Ivanis ${ }^{13}$
}

\begin{abstract}
Rezime
U sve većoj trci za tržišnim udelom kompanije, preduzeća svoje proizvodne i poslovne objekte geografski pozicioniraju poštujući nova pravila poslovanja. Da bi kompanija opstala na tržištu, potrebno je da maksimizira profit, minimizira troškove i zadrži dobar kvalitet $i$ konstantno ga unapređuje. Izbor lokacije predstavlja jednu od vitalnih odluka u procesu izgradnje proizvodnog sistema, iako je problem izbora lokacije vezan za određene vremenske preseke u životu datog proizvodnog sistema, potreba istraživanja uticaja lokacije stalna je u vremenu.

Cilj istraživačkog rada je u metodološkom pristupu izbora kriterijuma šire i uže lokacije za izgradnju proizvodnog sistema za proizvodnju testenina na teritoriji Vojvodine kao područja bogate sirovinske baze. Poljoprivredna i prehrambrena industrija su privredne grane sa dugom tradicijom, izuzetnim potencijalom u jačanju ekonomskih performasi privrede Vojvodine. Vrednovanje kriterijuma i njihova primena u modelu dimenzione analize omogućiće dobar odabir lokacije za izgradnju poslovnog sistema za proizvodnju testenina.
\end{abstract}

Ključne reči: lokacija preduzeća, šira lokacija, uža lokacija.

11 Goran Paunović M.Sc., Univerzitet Privredna akademija u Novom Sadu, Fakultet za ekonomiju i inženjerski menadžment u Novom Sadu, Cvećarska ulica br. 2, 21000 Novi Sad, Srbija, Telefon: +381 21400 484, E-Mail: paunovicgoran.ns@gmail.com

12 Redovni profesor, dr Dragan Solesa, Univerzitet Privredna akademija u Novom Sadu, Fakultet za ekonomiju i inženjerski menadžment u Novom Sadu, Cvećarska ulica br. 2, 21 000 Novi Sad, Srbija, Telefon: +381 21400 484, E-mail: solesadragan@gmail.com

13 Vanredni profesor, dr Marko Ivaniš, Univerzitet Privredna akademija u Novom Sadu, Fakultet za ekonomiju i inženjerski menadžment u Novom Sadu, Cvećarska ulica br. 2, 21 000 Novi Sad, Srbija, Telefon: +381 21400 484, E-mail: prof.drmivanis@gmail.com 